Research Article

\title{
The Ability of Spirulina sp. Microalgae as a Phytoremediation Agents in Liquid Waste of Handling Fish from Cemara Market, Medan
}

\author{
Astrid Fauzia Dewinta* (D), Eddie Satria Hartono, Eri Yusni, Ipanna Enggar Susetya, Rizky Febriansyah \\ Siregar
}

Program Study of Aquatic Resources Management, Faculty of Agriculture, Universitas Sumatera Utara, Medan, North Sumatera

\section{OPEN $\bigcirc$ ACCESS}

\section{ARTICLE INFO}

Received: July 24, 2020

Accepted: September 26, 2020

Published: September 27, 2020

*) Corresponding author:

E-mail:astridfd@usu.ac.id

Keywords:

Liquid waste of handling fish

Microalgae

Spirulina sp.

Phytoremediation

This is an open access article under the CC BY-NC-ND license (http://creativecommons.org/licenses/by-nc-nd/4.0/)

\begin{abstract}
Contamination material from fish market activities, namely fish handling liquid waste, is a problem facing the city of Medan today. Reduce the level of liquid waste pollutants can be done biologically by using microalgae organisms. One of them is like microalgae Spirulina sp. This study aims to determine the ability of Spirulina sp. for reducing the levels of pollutants in liquid waste of handling fish.The research method was use a Completely Randomized Design (CRD) with five treatments and three replications. Addition of $100 \mathrm{~mL}$ of inoculant Spirulina sp. with a density of $1 \times 10^{5} \mathrm{ind} / \mathrm{mL}$ of liquid waste mixed with fresh water with to reach a volume of $1000 \mathrm{~mL}$. Each liquid waste concentration of 30\%, 60\%, 80\%, $100 \%$, and control $(0 \%)$ added $1 \mathrm{~mL}$ Walne fertilizer. The results of initial measurements of liquid waste for parameters BOD, COD, TSS, ammonia, and phosphate, respectively are $26.50 \mathrm{mg} / \mathrm{L}, 4400 \mathrm{mg} / \mathrm{L}, 894 \mathrm{mg} / \mathrm{L}, 1.10 \mathrm{mg} / \mathrm{L}$, and $16.7 \mathrm{mg} / \mathrm{L}$. Based on the results, the best reduction in BOD level occured in the treatment of $30 \%(\mathrm{pA})$ of liquid waste is $17.64 \mathrm{mg} / \mathrm{L}$ with phytoremediation efficiency of $75.59 \%$. The best reduction in COD levels occurred in the treatment of $30 \%(\mathrm{pA})$ of liquid waste is $1301.12 \mathrm{mg} / \mathrm{L}$ with phytoremediation efficiency of $79.19 \%$. The best reduction in TSS levels occurred in the treatment of $60 \%(\mathrm{pB})$ of liquid waste is $411 \mathrm{mg} / \mathrm{L}$ with phytoremediation efficiency of $83.54 \%$. The best reduction in ammonia levels was at 30\% (pA) treatment, which was $0.38 \mathrm{mg} / \mathrm{L}$ with phytoremediation efficiency of $89.15 \%$. While the best decrease in phosphate levels occurred in the control treatment $(\mathrm{pK})$, which was $4.45 \mathrm{mg} / \mathrm{L}$ with phytoremediation efficiency of $97.35 \%$.
\end{abstract}

Citethisas: Dewinta, A. F., Hartono, E. S., Yusni, E., Susetya, I. E., Siregar, R. F. (2020). The Ability of Spirulina sp. Microalgae as a Phytoremediation Agents in Liquid Waste of Handling Fish from Cemara Market, Medan. Jurnal Ilmiah Perikanan dan Kelautan, 12(2): 286-295. http://doi.org/10.20473/jipk.v12i2.22224 


\section{Introduction}

The development of fishery agroindustry in addition to having a positive impact that is as a foreign exchange earner, providing added value and employment, also has a negative impact in the form of waste disposal. Megalina (2016), states that the Aliarn River Basin in the city shows a high level of waste pollution, increased anthropogenic activity causes environmental quality to decline. Environmental pollution problems due to fishing activities need to be watched out for. In this case the simplest method of treatment needs to be chosen and does not cost much, is biological treatment.Phytoremediation is a plant mediated technique to absorb pollutants by destroying, deactivating or immobilizing pollutants into harmless forms (Abdel-Shafy and Mansour, 2018). Biological water management methods can be carried out using organisms that reduce organic waste (Ahammad et al., 2013). One of them is the type of microalgae Spirulina sp. (Simamora et al., 2017).

Microalgae Spirulina sp. has high adaptability so that it is able to grow in various growth conditions (Lutzu, 2011). This type of algae can be found in waters with an alkaline or slightly acidic $\mathrm{pH}$ (Ismaiel et al., 2016). The condition of alkaline $\mathrm{pH}$ provides an advantage in terms of cultivation, because it is relatively not easily polluted by other microalgae which generally live at lower or more acidic $\mathrm{pH}$ (Abdel-Raouf et al.,2012).

Growth of Spirulina sp. a part from being influenced by nutrient content, it is also influenced by environmental conditions (Fagiri et al., 2013). Environmental factors that support the growth of Spirulina sp. are temperature, dissolved oxygen, salinity and pH (Uebel et al., 2019). The data from the measurement of water quality during the study showed that the $\mathrm{pH}$ ranged from 7.7 to 8.9. The $\mathrm{pH}$ value is an important factor for the growth of Spirulina sp. Most blue-green algae grow well at $\mathrm{pH} 7$ and are more resistant to alkaline than acidic conditions because they are able to utilize carbon dioxide available at low concentrations (Dejsungkranonta et al., 2012). A good $\mathrm{pH}$ for Spirulina sp. growth ranges from 6-8 (Rajasekaran et al., 2016).

One alternative to be able to maintain water quality and reduce organic waste compounds effectively and efficiently is touse the phytoremediation method, namely the use of Spirulina sp. (Khalila et al., 2018), in the management of fish organic liquid waste. In this case, the researchers wanted to reduce the levels of pollutants from liquid waste in fish handling from Pasar Cemara, Medan, North Sumatra by using the microalgae Spirulina sp.
This study aims to analyze the effect of the amount of waste concentration in removing pollutants using the phytoremediation method with Spirulina sp. from fish handling waste, and determine the efficiency of pollutant removal using the phytoremediation method with Spirulina sp. from waste water from fish handling.

\section{Materials and Methods}

\subsection{Time and Place of Research}

This research was be carried out in October to November 2019. This research was conducted in Aquaculture Laboratory of Aquatic Resources Management Study Program, Faculty of Agriculture, University of North Sumatra. For water measurements were carried out at BTKLPP (Medan Center for Environmental Health and Disease Control Engineering) Class I Medan.

\subsection{Materials}

The tools needed in this research are Transparent Bottles, Airstones, Aerated Hoses, Volume Pipettes, Drop Pipes, TL Lights 36 Watts, Measuring Cups, Pumpkin, Glass Funnels, Culture Bottles, Microscopes, pH Meters, Thermometers, TDS Meters, filter paper, Sedwick Rafter, and Jerry cans, the materials used in this study are as follows: Pure culture Spirulina sp., Organic waste handling fish, Water, Aquadest, 70\% alcohol, Chlorine, Teepol, Sodium thiosulfate, and Walne Fertilizer.

\subsection{Experimental design}

Culture of Spirulina sp. put into each of 15 transparent bottles containing media water with a total volume of each $1000 \mathrm{ml}$ bottle plus $100 \mathrm{ml}$ inoculants Spirulina sp., density Spirulina sp. used is $1 \times 10^{5}$ ind/ $\mathrm{mL}$. Then each of the five treatments with 3 replications. Spirulina sp. was culture for 7 days and given a light with 36-watt TL lamp. This research was conducted experimentally, the research design used was a Completely Randomized Design (CRD) consisting of five treatments with three replications with different waste concentrations with a volume of $1000 \mathrm{~mL}$, namely:

- Control treatment (pk) : 0\% liquid waste+ 100\% fresh water + WalneFertilizer $1 \mathrm{~mL}$

- Treatment A (pA): 30\% liquid waste $+70 \%$ fresh water

- Treatment B (pB): $60 \%$ liquid waste $+40 \%$ fresh water

- Treatment C (pC): $80 \%$ liquid waste $+20 \%$ fresh water

- Treatment D (pD): 100\% liquid waste 
JIPK.Volume 12 No 2. November 2020 / The Ability of Spirulina sp. Microalgae as a Phytoremediation Agents in Liquid.....

\subsection{Preparation of Containers}

Waste containers and aquarium box are sterilized by means of tools washed with teepol and rinsed with fresh water until clean, then sprayed with $70 \%$ alcohol, and allowed to dry in the air. The aeration hose and stones are sterilize with fluid cleaner then rinsed with fresh water. Then immersed with $0.2 \% \mathrm{HCl}$ for 24 hours and rinsed again with fresh water.

\subsection{Liquid Waste Sampling}

Liquid waste of handling fish used as a growing medium comes from Cemara market, Medan. Sample of liquid waste were taken from the liquid waste disposal control tub. It was put into plastic jerry cans with a volume of 20 liters. Then the liquid waste was analyzed in laboratory to find out the contents before entering microalgae for phytoremediation.

\subsection{Observation of Physics and Chemistry Parameters}

Measurement of water physic parameter is TSS and chemical parameters based on APHA (2005), are $\mathrm{pH}$, Ammonia ( $\mathrm{NH}^{-}$), BOD, COD and Phosphate $\left(\mathrm{PO}^{-}\right)$

Steps for measuring water quality for eachparameter, TSS measurements were carried out before stocking inoculants and at the end of retention when Spirulina sp. enter the death phase using a TSS meter. Then, ammonia measurements were carried out before stocking the inoculant and at the end of the retention when Spirulina sp. enter the death phase using a spectrophotometer. BOD measurements were taken before stocking the inoculant and at the end of retention when Spirulina sp. entering the death phase using a titration tool with the iodometric method. Then, COD measurements were carried out before stocking the inoculant and at the end of retention when Spirulina sp. enter the death phase using a spectrophotometer. Then, phosphate measurements were carried out prior to inoculants dispersion using spectrophotometry with a wave length of $650 \mathrm{~nm}$ in the sample. The phytoremediation efficiency then is calculated by using the formula (Sudjarwo et al., 2014):

Where:

$$
E f=\frac{C i-C e}{C i} \times 100 \%
$$

$\mathrm{Ef}=$ efficiency $(\%)$,

$\mathrm{Ci}=$ initial concentration $(\mathrm{mg} / \mathrm{L})$,

$\mathrm{Ce}=$ final concentration $(\mathrm{mg} / \mathrm{L})$.

\subsection{Analysis Data}

Data obtained in this research were water quality parameters. The data were then analyzed using the SPSS application for the ANOVA test at a level of $95 \%$. If the test results are significantly different between treatments then Duncan's further test is done at a level of $95 \%$.

\section{Results and Discussion}

\subsection{The characteristics of liquid waste of handling fish}

The characteristics of liquid waste of handling fish from Cemara market are known by measuring chemical and physical parameters (Table 1 )

Table 1. The characteristics of handling fish waste water in Cemara market

\begin{tabular}{lll}
\hline No Parameters & Result & Unit \\
\hline 1 Total Suspended Solid & 894 & $\mathrm{mg} / \mathrm{L}$ \\
2 Biochemical Oxygen Deman d(BOD) & 26.5 & $\mathrm{mg} / \mathrm{L}$ \\
3 Chemical Oxygen Demand (COD) & 4400 & $\mathrm{mg} / \mathrm{L}$ \\
4 Ammonia & 1.1 & $\mathrm{mg} / \mathrm{L}$ \\
5 Phosphate & 16.7 & $\mathrm{mg} / \mathrm{L}$ \\
\hline \multicolumn{2}{c}{ Based on physical } & and chemical \\
measurements, it is known that Total Suspended Solids \\
(TSS) 894 mg/L, Biochemical Oxygen Demand (BOD) \\
26.50 mg/L, Chemical Oxygen Demand (COD) 4400 \\
mg/L, Ammonia 1.10 mg/L, and Phosphate 16.7 mg/L.
\end{tabular}

\subsection{Total Suspended Solid(TSS)}

TSS is one of the important factors in decreasing water quality, causing changes in physics, chemistry, and biology. Physical changes include the addition of solids both organic and inorganic into the water, there by increasing turbidity, which in turn will inhibit the penetration of sunlight into water bodies. The reduced penetration of sunlight will affect the photosynthesis process carried out by phytoplankton and other aquatic plants. The amount of TSS that is in the waters can reduce the availability of dissolved oxygen (Hadiyanto et al., 2013) evaluate water quality, as well as determine the efficiency of handling units (Rinawati et al., 2016).

The measurement results of the parameters of TSS with microalgae of Spirulina sp. before and after being given liquid waste of handling fish with different amounts, namely, $\mathrm{K}$ (control), pA (30\% waste), pB (60\% waste), pC ( $80 \%$ waste) and pD (100\% waste) as follows in Table 2. 
Table 2. TSS phytoremediation efficiency values on Spirulina sp. in different treatments

\begin{tabular}{|c|c|c|c|c|c|}
\hline \multirow[b]{2}{*}{ Parameter } & \multicolumn{5}{|c|}{ Treatments (waste) } \\
\hline & $\begin{array}{l}\mathrm{pK} \\
(0 \%)\end{array}$ & $\begin{array}{c}\text { pA } \\
(\mathbf{3 0} \%)\end{array}$ & $\begin{array}{c}\mathrm{pB} \\
(\mathbf{6 0 \%})\end{array}$ & $\begin{array}{c}\mathrm{pC} \\
(\mathbf{8 0} \%)\end{array}$ & $\begin{array}{c}\text { pD } \\
(100 \%)\end{array}$ \\
\hline Before & $62 \pm 1.53$ & $331.67 \pm 0.65$ & $492.00 \pm 4.04$ & $768.00 \pm 5.20$ & $894 \pm 0.58$ \\
\hline After & $22 \pm 3.51$ & $69 \pm 1.73$ & $81.00 \pm 4.62$ & $149.00 \pm 2.89$ & $272.67 \pm 7.17$ \\
\hline $\begin{array}{l}\text { Decreased TSS } \\
\text { Levels (mg/L) }\end{array}$ & 40 & 262.67 & 411 & 619 & 621.33 \\
\hline $\begin{array}{l}\text { Phytoremediation } \\
\text { Efficiency (\%) }\end{array}$ & $64.67^{\mathrm{a}}$ & $79.19^{b}$ & $83.54^{\mathrm{b}}$ & $80.59^{\mathrm{b}}$ & $69.50^{2}$ \\
\hline
\end{tabular}

Description: The numbers followed by different letters, show significantly different $(\mathrm{p}<0.05)$.

Table2 shows that on the $9^{\text {th }}$ day, the efficiency of TSS phytoremediation in PB treatment (60\% waste) was $83.54 \%$ greater than treatment $\mathrm{K}$ (control) $64.67 \%$, treatment A (30\%waste) $79.19 \%$, treatment C $(680 \%$ waste) $80.59 \%$, and treatment D (100\% waste) $69.50 \%$. In the treatment of pA, namely the provision of $30 \%$ of liquid waste has met the quality standards according to the Ministry of Environment number 5 of 2014 which is $100 \mathrm{mg} / \mathrm{L}$.

Decreasing of TSS value is caused by the liquid waste obtained in Cemara market that already contains decomposing microorganisms that degrade pollutants and form floc called flocculation so that large solids become simpler. This refers to Qurbani (2015), besides containing suspended solids of wastewater it also often contains colloidal ingredients such as protein, TSS is generally removed by flocculation and filtering (Loera-Quezada et al., 2015).

Duncan's further test in Table 2 shows the treatment of pA (30\% of waste) pB ( $60 \%$ of waste), and $\mathrm{pC}$ ( $80 \%$ of waste) have a significant effect on the treatment of $\mathrm{pK}$ (control), and treatment of $\mathrm{pD}(100 \%$ of waste), this is because the decrease in TSS value is also related to the activity of nutrient absorption by microalgae to help the process of photosynthesis and the activity of decomposing bacteria. Substances that are large will decompose and demineralize them into smaller and simpler substances, there by reducing TSS cadets in each treatment. The process of metabolism and degradation of organic matter caused by decomposing bacteria will produce inorganic compounds. According to Pamungkas (2016), the liquid waste in the fishing industry contains a lot of protein and fat, resulting in quite high nitrate and ammonia values. Decomposition of fishery products is caused by the decomposition of proteins, fats, and carbohydrates in the body's tissues of fisheries by decomposing bacteria (Delgadillo-Mirquez et al., 2016).

\subsection{Biochemical Oxygen Demand (BOD)}

BOD indicates the amount of oxygen needed by decomposers (bacteria) to decompose organic matter into inorganic materials (aerobic decomposition) over a certain period of time, so BOD shows the level of oxygen demand for the biological decomposition process. High and low BOD is determined by temperature, plankton density, the presence of microbes and the type and presence of organic matter contained in the waters (Asmara, 2005). Measurement of the level of Biological Oxygen Demand (BOD) in waste water is used to determine the amount of dissolved $\mathrm{O}_{2}$ needed by aerobic microorganisms to oxidize organic material in a waste sample.

The measurement results of the parameters Biochemical Oxygen Demand (BOD) Microalgae Spiruli na sp. before and after the fish handler's liquid organic waste, namely, $\mathrm{K}$ treatment (control), pA (30\% waste), $\mathrm{pB}$ (60\% waste), $\mathrm{pC}(80 \%$ waste) and $\mathrm{pD}$ (100\% waste) follows in Table 3.

Table 3 shows that the concentration of Spirulina sp. with different levels of waste content can reduce the value of the $\mathrm{BOD}$ content contained in fish handling liquid waste. The BOD level decreases along with the less variation of fish handling liquid waste in each treatment. Table 3 shows the phytoremediation efficiency of BOD pA (30\% liquid waste) of $75.59 \%$ greater than treatment control of $52.11 \%$, pB $(60 \%$ liquid waste) of $60.44 \%$, pC (80\% liquid waste) of $26.78 \%$, and $\mathrm{pD}$ (100\% waste) $9.74 \%$.

Liquid waste of handling fish is not too large in the cultivation medium can increase phytoremediation efficiency by Spirulina sp. because it does not affect the penetration of light into the media so that it further improves the phytoremediation process. Photosynthesis of microalgae produces $\mathrm{O}_{2}$ which plays a role for respiration in the growth 
of waste oxidizing bacteria, conversely oxidation reactions or decomposition of waste carried out by bacteria produce $\mathrm{CO}_{2}$ which can support the growth of microalgae, this will also speed up the process of decomposition of waste carried out. BOD according to Cahyanto et al. (2018), BOD is the amount of dissolved oxygen needed by decomposing bacteria to decompose organic pollutants in water. The greater the BOD concentration of a waters, shows the concentration of organic matter in the water is also high organic material must be degraded by microorganisms (Olguín et al., 2001).

\subsection{Chemical Oxygen Demand (COD)}

Measurement the level of Chemical Oxygen Demand (COD) in liquid waste is used to determine how much the level of pollution in water bodies by organic matter. COD is a description of the total oxygen needed to chemically oxidize organic material, both biodegradable and non-biodegradable, into $\mathrm{CO}_{2}$ and $\mathrm{H}_{2} \mathrm{O}$. The existence of organic material can come from nature or human activities through households and industry COD value in uncontaminated waters is

Table 3. BOD phytoremediation efficiency values on Spirulina sp. in different treatments

\begin{tabular}{|c|c|c|c|c|c|}
\hline \multirow[b]{2}{*}{ Parameter } & \multicolumn{5}{|c|}{ Treatments (waste) } \\
\hline & $\begin{array}{c}\mathrm{pK} \\
(\mathrm{mg} / \mathrm{L})\end{array}$ & $\begin{array}{c}\mathrm{pA} \\
(\mathrm{mg} / \mathrm{L})\end{array}$ & $\begin{array}{c}\mathrm{pB} \\
(\mathrm{mg} / \mathrm{L})\end{array}$ & $\begin{array}{c}\mathrm{pC} \\
(\mathrm{mg} / \mathrm{L})\end{array}$ & $\begin{array}{c}\mathrm{pD} \\
(\mathrm{mg} / \mathrm{L})\end{array}$ \\
\hline Before & $4.74 \pm 0.04$ & $23.33 \pm 0.73$ & $17.83 \pm 0.81$ & $26.33 \pm 0.44$ & $27.17 \pm 0.44$ \\
\hline After & $2.27 \pm 0.14$ & $5.69 \pm 0.18$ & $10.15 \pm 2.05$ & $19.28 \pm 0.33$ & $24.52 \pm 0.40$ \\
\hline $\begin{array}{l}\text { Decreased BOD } \\
\text { Levels }\end{array}$ & 2.47 & 17.64 & 7.68 & 7.05 & 2.65 \\
\hline $\begin{array}{l}\text { Phytoremediation } \\
\text { Efficiency }\end{array}$ & $52.11 \%^{c}$ & $75.59 \% \mathrm{e}^{\mathrm{e}}$ & $60.44 \%^{\mathrm{d}}$ & $26.78 \%{ }^{b}$ & $9.74 \% \mathrm{o}^{\mathrm{a}}$ \\
\hline
\end{tabular}

Table 4. COD phytoremediation efficiency values on Spirulina sp. in different treatments

\begin{tabular}{|c|c|c|c|c|c|}
\hline \multirow[b]{2}{*}{ Parameter } & \multicolumn{5}{|c|}{ Treatments (waste) } \\
\hline & $\begin{array}{c}\mathrm{pK} \\
(\mathrm{mg} / \mathrm{L})\end{array}$ & $\begin{array}{c}\mathbf{p A} \\
(\mathbf{m g} / \mathbf{L})\end{array}$ & $\begin{array}{c}\mathrm{pB} \\
(\mathrm{mg} / \mathrm{L})\end{array}$ & $\begin{array}{c}\mathrm{pC} \\
(\mathrm{mg} / \mathrm{L})\end{array}$ & $\begin{array}{c}\mathrm{pD} \\
(\mathrm{mg} / \mathrm{L})\end{array}$ \\
\hline Before & $54.2 \pm 1.89$ & $1560.6 \pm 36.55$ & $2522.3 \pm 11.86$ & $3007.6 \pm 0.33$ & $4421 \pm 222.52$ \\
\hline After & $20.7 \pm 2.39$ & $259.5 \pm 15.15$ & $1469.1 \pm 57.07$ & $2285.2 \pm 316.64$ & $3591.5 \pm 59.79$ \\
\hline $\begin{array}{l}\text { Decreased COD } \\
\text { Levels }\end{array}$ & 33.5 & 1301.12 & 1053.26 & 722.48 & 829.54 \\
\hline $\begin{array}{l}\text { Phytoremediation } \\
\text { Efficiency }\end{array}$ & $61.70 \%{ }^{\mathrm{bc}}$ & $79.19 \% \mathrm{c}^{\mathrm{c}}$ & $41.77 \%$ ab & $24.02 \%{ }^{b}$ & $18.85 \% \%^{\mathrm{a}}$ \\
\hline
\end{tabular}

Description: The numbers followed by different letters, show significantly different $(p<0.05)$.

Duncan's follow up test in Table 3 shows that all the treatments, both pK (control), pA (30\% waste), pB (60\% waste), pC (80\% waste) and pD (100\% waste) are significantly different from each other, this because the decrease in BOD is in line with the decrease in the content of organic matter in organic waste water handling fish, oxygen produced from the metabolism of microalgae Spirulina sp. that is photosynthesis, this increased oxygen content in wastewater will increase the process of decomposition of aerobic bacteria so that it can suppress high levels of BOD in water. According to Cahyanto et al. (2018), BOD value is influenced by the presence of plants that cover the surface of wastewater. The existence of these plants absorbs organic substances found in wastewater. The more photosynthetic organisms, the more organic material is absorbed and the organic material must be degraded by microorganisms (Olguín et al., 2001). usually less than $20 \mathrm{mg} / \mathrm{l}$, whereas in polluted waters can be more than $200 \mathrm{mg} / \mathrm{l}$ (Wijaya, 2009).

The measurement results for the range of changes in the value of the Chemical Oxygen Demand (COD) Microalgae Spirulina sp. before and after being giv- en liquid waste of handling fish from Pasar Cemara, Medan with different amounts, namely, $\mathrm{K}$ (control), pA (30\% waste), pB (60\% waste), pC (80\% waste) and $\mathrm{pD}$ (100\% waste) as follows in Table 4.

Phytoremediation level Spirulina $s p$. in absorbing levels of Chemical Oxygen Demand (COD) pollutants shows a positive value. This value was decrease in line with the increase population of Spirulina sp. The level of Chemical Oxygen Demand (COD) is smaller (decreased) than the initial value before cultivation. 
The data show a significantly different treatment at $30 \%$ pA concentration compared to other liquid waste concentrations. The decrease in pollutants shows the value of phytoremediation efficiency of COD in the treatment of pA (30\% waste) $79.19 \%$ greater than $\mathrm{pK}$ (control) $61.70 \%, \mathrm{pB}(60 \%$ waste) $41.77 \%$, pC (80\%waste) $24.02 \%$ and pD (100\% waste) $18.85 \%$.

In Table 4 shows the less waste, the greater the phytoremediation efficiency produced. This is because the greater the level of waste will increase the organic material in it so that it affects the penetration of light into the media. Large light penetration will increase the metabolic activity of Spirulina sp. There by increasing the absorption of COD pollutants. In accordance with Cahyanto et al. (2018), Spirulina sp. has a high phytoremediation ability (efficiency above $75 \%$ ) at a wastewater concentration of $25 \%$. Decreasing the concentration of organic wastewater optimizes the absorption of pollutants and can be safely disposed of in water bodies (Pacheco et al., 2015).

Duncan's further test in Table 4 shows the treatment of $\mathrm{pA}$ ( $30 \%$ of waste) has a significant influence on the treatment of $\mathrm{pK}$ (control), $\mathrm{pB}(60 \%$ of waste), pC ( $80 \%$ of waste), and $\mathrm{pD}$ (100\% of waste), this is because a decrease in the value of COD causes oxygen to be higher. This is caused by the presence of microalgae Spirulina sp. which absorbs organic material from liquid waste, so that oxygen consumption by microbes to degrade organic matter becomes less. According to Siregar et al. (2017), the high value of COD indicates the high organic matter in the research media. The contribution of organic matter from dead plants is not balanced by the utilization of nutrients resulting from the decomposition of organic material caused by the small number of plants in the treatment.

\subsection{Ammonia}

Ammonia $\left(\mathrm{NH}_{3}\right)$ and its salts are soluble inwater. The source of ammonia in waters is the breakdown of organic nitrogen (protein and urea) and inorganic nitrogen present in the soil and water, which comes fromthe decomposition of organic matter (dead aquatic plants and biota) by microbes and fungi (Effendi, 2003).

The measurement results of ammonia microalgae Spirulina sp. before and after being given liquid waste of handling fish from Cemara market, Medan with different amounts, namely, $\mathrm{K}$ (control), pA (30\% waste), pB (60\% waste), $\mathrm{pC}(80 \%$ waste) and $\mathrm{pD}$ (100\% waste) as follows in Table 5.

Table 5 shows the value of phytoremediation efficiency of ammonia in the treatment of greater $\mathrm{pA}$ (30\% waste) $89.15 \%$ than $\mathrm{pK}$ (control) $32.22 \%$, pB (60\% waste) $59.45 \%$, pC (80\% waste) $63.37 \%$ and PD (100\% waste) $69.39 \%$ and have met the quality standards according to the Ministry of Environment. No. 5 of 2014 which is $5 \mathrm{mg} / \mathrm{L}$. This is due to the population of Spirulina sp. higher than $\mathrm{pB}, \mathrm{pC}$ and $\mathrm{pD}$ so that the microalgae absorb more ammonia in treatment A compared to other treatments.

At least the ammonia material used by Spirulina sp. for phytoremediation and degradation by microbes also causes ammonia in treatment $\mathrm{A}$ to be less than other treatments. According to Effendi (2003), the source of ammonia in waters is the breakdown of organic nitrogen (protein and urea) and inorganic nitrogen found in soil and water, which comes from the decomposition of organic matter.

Duncan's further test in Table 5 shows the treatment of pA (30\% waste) has a significant effect on the treatment of $\mathrm{pK}$ (control), pB (60\% waste), pC (80\% waste) and $\mathrm{pD}(100 \%$ waste), this is because the high value of ammonia reduction in treatment is in line with the large population of Spirulina sp. which grows and develops in the treatment. Because ammonia contains nitrogen compounds that are needed by microalgae for growth. In accordance with Elystia et al. (2019), ammonia is the main source of nitrogen compounds other than nitrates that can be used by microalgae for their metabolic processes, while the use of nitrites is limited by their toxicity.

Table 5. Ammonia phytoremediation efficiency values on Spirulina sp. in different treatments

\begin{tabular}{|c|c|c|c|c|c|}
\hline \multirow[b]{2}{*}{ Parameter } & \multicolumn{5}{|c|}{ Treatments } \\
\hline & $\begin{array}{c}\mathrm{pK} \\
(\mathrm{mg} / \mathrm{L})\end{array}$ & $\begin{array}{c}\mathrm{pA} \\
(\mathrm{mg} / \mathrm{L})\end{array}$ & $\begin{array}{c}\mathrm{pB} \\
(\mathrm{mg} / \mathrm{L})\end{array}$ & $\begin{array}{c}\mathrm{pC} \\
(\mathrm{mg} / \mathrm{L})\end{array}$ & $\begin{array}{c}\mathrm{pD} \\
(\mathrm{mg} / \mathrm{L})\end{array}$ \\
\hline Before & $3.2 \pm 0.07$ & $0.43 \pm 0.02$ & $0.61 \pm 0.02$ & $0.85 \pm 0.03$ & $1.05 \pm 0.08$ \\
\hline After & $2.17 \pm 0.23$ & $0.05 \pm 0.01$ & $0.25 \pm 0.03$ & $0.31 \pm 0.01$ & $0.32 \pm 0.03$ \\
\hline $\begin{array}{l}\text { Decreased } \\
\text { Ammonia Levels }\end{array}$ & 1.03 & 0.38 & 0.36 & 0.54 & 0.73 \\
\hline $\begin{array}{l}\text { Phytoremediation } \\
\text { Efficiency }\end{array}$ & $32.22 \% 0^{\mathrm{a}}$ & $89.15 \%{ }^{\mathrm{c}}$ & $59.45 \%{ }^{\mathrm{b}}$ & $63.37 \%^{b}$ & $69.39 \%$ b \\
\hline
\end{tabular}

Description: The numbers followed by different letters, show significantly different $(p<0.05)$. 


\subsection{Phosphate}

Phosphate is one of the mineral elements which is an essential element in feed. Phosphate with sulfur is a mineral contained in organic compounds which acts as a constituent of various proteins. The use of these elements affects the manufacture of fish feed. The mineral element is known as inorganic material or ash content which functions as a builder and regulator. Phosphate is often considered alimiting factor, which is based on the fact that phosphate is in dispensable in the transfer of $\mathrm{P}$ energy in organism cells. Very small amounts of phosphate will cause nutrient deficiencies that can suppress the growth of phytoplankton, and ultimately reduce productivity in a water (Baharsyah, 2014).

The measurement results of phosphate microalgae Spirulina sp. before and after being given liquid waste of handling fish from Cemara market, Medan with different amounts, namely, $\mathrm{K}$ (control), pA (30\% waste), pB (60\% waste), pC (80\% waste) and $\mathrm{pD}(100 \%$ waste) as follows in Table 6.
Duncan's further test in Table 6 shows the pK (control) treatment is significantly different from the treatment of pA (30\% waste), pB $(60 \%$ waste), pC (80\% waste) and pD treatment (100\% waste), this is because the high absorption rate of phosphate in treatment $\mathrm{K}$ was $97.25 \%$ because it was followed by high population of microalgae Spirulina sp. The element of phosphate in water is used by microalgae to continue to grow and grow. This is in accordance with Handajani (2006), Spirulina sp. is one of the microalgae that is cosmalite which can be cultivated in different mediums. Spirulina sp. growth requires the availability of nutrients $\mathrm{N}$ and $\mathrm{P}$ which can be derived from chemicals or decomposed solutions or waste for growth.

\section{Conclusion}

Based on the results, it can be concluded that the addition of Spirulina sp. at a volume of 100 $\mathrm{ml}$ with a density were $1 \times 10^{5} \mathrm{ind} / \mathrm{mL}$ with a variation in the levels of liquid waste of handling

Table 6. Phosphate phytoremediation efficiency values on Spirulina sp. in different treatments

\begin{tabular}{|c|c|c|c|c|c|}
\hline \multirow[b]{2}{*}{ Parameter } & \multicolumn{5}{|c|}{ Treatments (waste) } \\
\hline & $\begin{array}{c}\text { pK } \\
(\mathrm{mg} / \mathrm{L})\end{array}$ & $\begin{array}{c}\mathbf{p A} \\
(\mathbf{m g} / \mathbf{L})\end{array}$ & $\begin{array}{c}\mathrm{pB} \\
(\mathrm{mg} / \mathrm{L})\end{array}$ & $\begin{array}{c}\mathrm{pC} \\
(\mathrm{mg} / \mathrm{L})\end{array}$ & $\begin{array}{c}\mathrm{pD} \\
(\mathrm{mg} / \mathrm{L})\end{array}$ \\
\hline Before & $4.58 \pm 0.19$ & $20.23 \pm 3.78$ & $21.4 \pm 2.46$ & $22.4 \pm 4.35$ & $22.67 \pm 4.84$ \\
\hline After & $0.13 \pm 0.06$ & $11.2 \pm 2.11$ & $12.49 \pm 1.54$ & $15.74 \pm 3.28$ & $16.5 \pm 3.54$ \\
\hline $\begin{array}{l}\text { Decreased } \\
\text { Phosphate Levels }\end{array}$ & 4.45 & 9.03 & 8.91 & 6.66 & 6.17 \\
\hline $\begin{array}{l}\text { Phytoremediation } \\
\text { Efficiency }\end{array}$ & $97.35 \% \mathrm{c}$ & $44.70 \%{ }^{\mathrm{b}}$ & $41.51 \%{ }^{b}$ & $30.27 \% 0^{a}$ & $27.23 \%$ \\
\hline
\end{tabular}

Description: The numbers followed by different letters, show significantly different $(p<0.05)$.

Table 6 shows that phosphate phytoremediation efficiency values in the treatment were greater $\mathrm{pK}$ (control) $97.25 \%$ than $\mathrm{pA}(30 \%$ waste) $44.70 \%$, pB (60\% waste) $41.51 \%$, pC (80\% waste) $30.27 \%$ and PD (100\% waste) $27.23 \%$. This shows the growth of Spirulina sp. in organic waste can decrease phosphate levels.

The increase in algal cell density is in line with the amount of nutrients needed for its metabolic process. That phosphate is one of the important nutrients in the growth and development of Spirulina sp. The greater the $\mathrm{P}$ element in a microalga cultivation medium, the faster the microalgae grows and develops. According to Baharsyah (2014), Phosphate is often regarded as alimiting factor, which is based on the fact that phosphate is indispensable in the transfer of $\mathrm{P}$ energy in organism cells. Very small amounts of phosphate will cause nutrient deficiency which can suppress the growth of phytoplankton. fish can reduce the content of these pollutants. Different levelsof liquid waste have a significant effect on the value of TSS, BOD, COD, ammonia, and phosphate in reducing the load of the waste pollutant. The best reduction in BOD level occured in the treatment of $30 \%(\mathrm{pA})$ of liquid waste is 17.64 $\mathrm{mg} / \mathrm{L}$ with phytoremediation efficiency of $75.59 \%$. The best reduction in COD levels occurred in the treatment of $30 \%(\mathrm{pA})$ of liquid waste is 1301.12 $\mathrm{mg} / \mathrm{L}$ with phytoremediation efficiency of $79.19 \%$. The best reduction in TSS levels occurred in the treatment of $60 \%(\mathrm{pB})$ of liquid waste is $411 \mathrm{mg} / \mathrm{L}$ with phytoremediation efficiency of $83.54 \%$. The best reduction in ammonia levels was at 30\% (pA) treatment, which was $0.38 \mathrm{mg} / \mathrm{L}$ with phytoremediation efficiency of $89.15 \%$. While the best decrease in phosphate levels occurred in the control treatment (pK), which was $4.45 \mathrm{mg} / \mathrm{L}$ with phytoremediation efficiency of $97.35 \%$. 


\section{Acknowledgment}

We thank to Panji Wibowo Hasyim, Aminah Asrah Siregar, Olivia Rosaline Pasaribu and Ika Surya Agustiani for assistance during this research when we do experimental research at BTKLP Laboratory.

\section{Authors' Contributions}

AFD devised the main conceptual ideas forthis research, make an analysis for results in this article,and draft the manuscript. ESH collected sample and data, did experiment on a laboratory, make an analysis for data results. EY, IES, and RFS discussed the resultsand contributed to the final manuscript.

\section{Conflict of Interest}

The authors declare that they have no competing interests

\section{Funding Information} funds.

This Research was conducted on independent

\section{References}

Abdel-Raouf, N., Al-Homaidan, A. A., \& Ibraheem, I. B. M. (2012). Microalgae and Wastewater Treatment. Saudi Journal of Biological Sciences. 19 (3): 257-275.

Abdel-Shafy, H. I., \& Mansour, M. S. M. (2018), Phytoremediation for the Elimination of Metals, Pesticides, PAHs, and Other Pollutants from Wastewater and Soil. In: Kumar V., Kumar M., Prasad R. (eds) Phytobiont and Ecosystem Restitution. Springer, Singapore.

Ahammad, S. Z., Graham, D. W., \& Dolfing, J. (2013). Wastewater Treatment: Biological. In book: Encyclopedia of Environmental Management. Pp. 26452655. Taylor and Francis Publisher. DOI:10.1201/9781003045045-61.

Asmara, A. (2005). Hubungan Struktur Komunitas Plankton dengan Kondisi Fisika-Kimia Perairan Pulau Pramuka dan Pulau Panggang, KepulauanSeribu. Institut Pertanian Bogor, Bogor.

Astiani, F., I. Dewiyanti, \& S. Mellisa. (2016). Pengaruh Media Kultur yang Berbeda Terhadap Laju Pertumbuhan dan Biomassa Spirulina sp. Jurnal Ilmiah Mahasiswa Kelautan dan Perikanan Unsyiah. 1 (3): 441-447. ISSN. 25276395.
Baharsyah, A. M. (2014). Pelepasan Fosfor dari Keramba Jaring Apung Ikan Mas (Cyprinus Carpio) di Waduk Cirata. Institut Pertanian Bogor, Bogor.

Cahyanto, T., T. Sudjarwo, S. P. Larasati, A. Fadillah. (2018). Fitoremediasi Air Limbah Pencelupan Batik Parakannyasag Tasikmalaya Menggunakan $\mathrm{Ki}$ Apu (Pistia stratiotes L.). Scripta Biologica. 5 (2) :83-89.

Dejsungkranont, M., Phoopat, N., \& Sirisansaneeyakul, S. (2012). Optimization of the Biomass Production of Arthrospira (Spirulina) Using Taguchi Method. The Open Conference Proceedings Journal. 3:70-81.

Delgadillo-Mirquez, L., Lopes, F., Taidi B., \& Pareau, D. (2016). Nitrogen and phosphate removal from wastewater with a mixed microalgae and bacteria culture. Biotechnology Reports. 11: 18-26.

Effendi, H. (2003). Telaah Kualitas Air. Penerbit Kanisius. Yogyakarta.

Ekantari, N., Y. Marsono, Y. Pranoto, \& E. Harmayani. (2017). Pengaruh Media Budidaya Menggunakan Air Laut dan Air Tawar terhadap Sifat Kimia dan Fungsional Biomassa Kering Spirulina platensis. Agritech. 37(2):173-182.

Elystia, S., S. R. Muria, \& S. I. P. Pertiwi. (2019). Pemanfaatan Mikroalga Chlorella sp. untuk Produksi Lipid dalam Media Limbah Cair Hotel dengan Variasi Rasio C:N dan Panjang Gelombang Cahaya. Jurnal Sains dan Teknologi Lingkungan, 11(1): 25-43.

Fagiri, Y. M. A., Salleh, A., \& El-Nagerabi, S. A. F. (2013). Impact of Physico-Chemical Parameters On The Physiological growth of Arthrospira (Spirulina platensis) Sexogenous Strain UTEXLB2340. African Journal of Biotechnology. 12 (35): 5458-5665.

Hadiyanto \& M. Christwardanaa. (2012). Aplikasi Fitoremediasi Limbah Jamu dan Pemanfaatannya untuk Produksi Protein. Jurna lIlmu Lingkungan, 10(1): 129-134.

Hadiyanto, Christwardana, M., Soetrisnanto, D. (2013). Phytoremediations of palm oil mill effluent (POME) using aquatic plants and microalgae for biomass production. Journal of Environmental Science and Technology. 6(2): 79-90.

Handajani, H. (2006). Pemanfaatan Limbah Cair Tahu sebagai Pupuk Alternatif pada Kultur Mikroalga Spirullina sp. Jurnal Protein. 13(2). 
Ismaiel, M. M. S., El-Ayouty, Y. M., \& Normorea, M. P. (2016). Role of $\mathrm{pH}$ on antioxidants production by Spirulina (Arthrospira) platensis. Brazilian Journal of Microbiology. 47(2): 298-304.

Khalila, H. S., Fayed. W. M., Mansour, A. T., Srour, T. M., Omar, E. A., Darwish, S. I., \& Nour, A. A. M. (2018). Dietary Supplementation of Spirulina, Arthrospira platensis, with Plant Protein Sources and their Effects on Growth, Feed Utilization and Histological Changes in Nile Tilapia, Oreochromis niloticus. Journal of Aquaculture Research \& Development. 9(10):1-9.

Loera-Quezada, M. M., Leyva-González, M. A., López-Arredondo, D., Herrera-Estrella, L. (2015). Phosphite cannot be used as a phosphorus source but is non-toxic for microalgae. Plant Science. 231: 124-130.

Lutzu, G. A. (2011). Analysis of the growth of microalgae in batch and semi-batch photobioreactors. [Disertasi]. Universita Degli Studi di Cagliari, Cagliari.

Megalina, Y. (2016). Menganalisis Pencemaran Daerah Aliran Sungai (DAS) Akibat Limbah Domestik di kota Medan. Jurnal Ikatan Alumni Fisika Universitas Negeri Medan. 2 (2). ISSN : 2461-124759.

Muliani, Ayuzar E., \& Amri, M. C. (2018). Pengaruh Pemberian Pupuk Kascing (Bekas Cacing) yang di Fermentasi dengan Dosis yang Berbeda dalam Kultur Spirulina sp. Acta Aquatica: Aquatic Sciences Journal, (5)1: 30-35.

Olguín, E. J., Galicia, S., Angulo-Guerrero, O., \& Hernández, E. (2001). The Effect of Low Light Flux and Nitrogen Deficiency on the Chemical Composition of Spirulina sp. (Arthrospira) Grown on Digested Pig Waste. Bioresource Technology. 77(1): 19-24.

Pacheco, M. M., Hoeltz, M., Moraes, M.S., Schneider, R.C. (2015). Microalgae: Cultivation Techniques and Wastewater Phycoremediation. Journal of Environmental Science and Health. 50(6): 585-601.

Pamungkas, M. T. O. A. (2016). Studi Pencemaran Limbah Cair dengan Parameter BOD5 Dan pH di Pasar Ikan Tradisional dan Pasar Modern di Kota
Semarang. Jurnal Kesehatan Masyarakat. 4 (2): 166-175.

Prasadi, O. (2018). Pertumbuhan dan Biomasa Spirulina sp. dalam Media Pupuk sebagai Bahan Pangan Fungsional. Jurnal Ilmu Perikanan Kelautan. (10) 2: 119-123.

Pratama, E. (2017). Fitoremediasi Limbah Budidaya Pendederan Kerapu Bebek (Cromileptes altivelis) Menggunakan Spirulina sp. Universitas Lampung, Bandar Lampung

Qurbani, N. P. (2015). Deteksi Kualitas Air Menggunakan Bentos di Sungai Way Sekampung, Metro Kibang Lampung Timur. Universitas Lampung, Bandar Lampung.

Rajasekaran, C., Ajeesh, C. P. M., Balaji S., Shalini, M., Siva, B., Das, R., Fulzele, D. P., \& Kalaivani, T. (2016). Effect of Modified Zarrouk's Medium on Growth of Different Spirulina Strains. Walailak Journal of Science \& Technology. 13(1): 67-75.

Rinawati, D., Hidayat, R. Suprianto, \& P. S. Dewi. (2016). Penentuan Kandungan Zat Padat (Total Dissolve Solid dan Total Suspended Solid) di Perairan Teluk Lampung. Analit: Analytical and Environmental Chemistry.1(1).

Sigiro, P. S., \& Rokaya, E. (2016). Efektifitas Penyerapan Timbal (Pb) oleh Bunga Matahari (Helianthus annuus LINN) menggunakan Penambahan Mikoriza dan Edta. UAJY. Universitas Dipenogoro, Semarang.

Simamora, L. A., Sudarno, \& T. Istirokhatun. (2017). Kultivasi Mikroalga sebagai Metode Pengolahan dalam Menyisihkan Kadar COD dan Amonium pada Limbah Cair Tahu. Jurnal Teknik Lingkungan. 6(1): 1-14.

Siregar, A., D. Jubaedah, \& M. Wijayanti. (2017). Penggunaan Hydrilla verticillata sebagai Fitoremediator dalam Pemeliharaan Ikan Patin (Pangasius sp.). Jurnal Akuakultur Rawa Indonesia, 5(1) :70-82.

Sudjarwo T, N. Nisyawati, Rossiana, \& W. Mangunwardoyo. (2014). The growth of water hyacinth (Eichhornia crassipes (Mart.) Solms) and water lettuce (Pistia 
JIPK.Volume 12 No 2. November 2020 / The Ability of Spirulina sp. Microalgae as a Phytoremediation Agents in Liquid.....

stratiotes L.) in domestic wastewater in wastewater treatment plant (WWTP) Bojongsoang, Bandung, Indonesia. Journal of Biodiversity and Environmental Sciences. 5(4):393-401.

Uebel, L. S., Costa, J. A. V., Olson, A. C., \& Morais, M. G. (2019). Industrial Plant For Production Of Spirulina sp. LEB 18. Brazilian Journal of Chemical Engineering. 36(1).
Wahyuni, N., E. D. Masithah, W. Soemarjati, Suciyono, \& M. F. Ulkhaq. (2018). Pola Pertumbuhan Mikroalga Spirulina sp. Skala Laboratorium yang dikultur Menggunakan Wadah yang Berbeda. Majalah Ilmiah Bahari Jogja,16(2): 89-97.

Wijaya, H. K. (2009). Komunitas Perifiton dan Fitoplankton Serta Parameter Fisika Kimia Perairan sebagai Penentu Kualitas Air di Bagian Hulu Sungai Cisadane, Jawa Barat. Institut Pertanian Bogor, Bogor. 